\title{
Hydroclimatic change disparity of Peruvian Pacific drainage catchments
}

\author{
Pedro Rau ${ }^{1}$ (D) Luc Bourrel $^{1}$ - David Labat ${ }^{1} \cdot$ Frédéric Frappart $^{1,2}$ - Denis Ruelland ${ }^{3}$. \\ Waldo Lavado $^{4} \cdot$ Boris Dewitte $^{2,5,6} \cdot$ Oscar Felipe $^{4}$
}

Received: 12 February 2016 / Accepted: 23 August 2017

(C) Springer-Verlag GmbH Austria 2017

\begin{abstract}
Peruvian Pacific drainage catchments only benefit from $2 \%$ of the total national available freshwater while they concentrate almost $50 \%$ of the population of the country. This situation is likely to lead a severe water scarcity and also constitutes an obstacle to economic development. Catchment runoff fluctuations in response to climate variability and/or human activities can be reflected in extreme events, representing a serious concern (like floods, erosion, droughts) in the study area. To document this crucial issue for Peru, we present here an insightful analysis of the water quantity resource variability of this region, exploring the links between this variability and climate and/or anthropogenic pressure. We first present a detailed analysis of the hydroclimatologic variability at annual timescale and at basin scale over the 1970-2008 period. In addition to corroborating the influence of extreme El Niño events over precipitation and runoff in northern catchments, a mean warming of
\end{abstract}

Pedro Rau

pedro.rau@get.obs-mip.fr

1 UMR 5563 GET, Université de Toulouse - CNRS-IRD-OMP-CNES, 14 Avenue Edouard Belin, 31400 Toulouse, France

2 UMR 5566 LEGOS, Université de Toulouse CNRS-IRD-OMP-CNES, 14 Avenue Edouard Belin, 31400 Toulouse, France

3 CNRS, UMR 5569 HydroSciences Montpellier, 300 Avenue du Professeur Emile Jeanbrau, 34095 Montpellier, France

4 SENAMHI, Jirón Cahuide 785, 11 Lima, Peru

5 Facultad de Ciencias del Mar, Universidad Católica del Norte, Coquimbo, Chile

6 Centro de Estudios Avanzado en Zonas Áridas (CEAZA), Coquimbo, Chile
$0.2{ }^{\circ} \mathrm{C}$ per decade over all catchments was found. Also, higher values of temperature and potential and actual evapotranspiration were found over northern latitudes. We chose to apply the Budyko-Zhang framework that characterizes the water cycle as a function of climate only, allowing the identification of catchments with significant climatic and anthropogenic influence on water balance. The Budyko-Zhang methodology revealed that 11 out of 26 initial catchments are characterized by low water balance disparity related to minor climatic and anthropogenic influence. These 11 catchments were suitable for identifying catchments with contrasting change in their hydroclimatic behavior using the Budyko trajectories. Our analysis further reveals that six hydrological catchment responses can be characterized by high sensitivity to climate variability and land use changes.

\section{Introduction}

Changes in climatic conditions appear as more sensitive in dryland regions around the world. In these regions, the effects of climate variability and human activities on runoff are significantly more visible than in other climate regions (Mortimore 2009), resulting in a reduction or increase in water yield (Brown et al. 2005; Donohue et al. 2011; Chen et al. 2013).

Catchments in the Peruvian Pacific drainage region (hereafter Pd) are characterized by dryland conditions (e.g., arid and semiarid areas), implying water shortage problems for human consumption and economical activities in major cities located at lowlands. Besides, they are likely to be affected by the devastating effects of floods (ANA 2012). Previous studies such as Lavado et al. (2012) showed evidence of lack of uniform regional trend and changes mainly in minimum runoff, which they attributed to the anthropogenic influence over 
the 29 catchments that were analyzed. Earlier studies (ANA 2012) analyzed the water supply and demand in the main catchments as an approximation of water balance with water management purposes.

Quantifying and deciphering the effects of climate variability and human activities on hydrological regime represent a major challenge, especially at short scales of time and space (Donohue et al. 2007; Wagener et al. 2010). In order to decipher climate variability and anthropogenic influence on water balance, we based our study on the Budyko theory (Budyko 1958, 1974). This theory is widely used and is a wellestablished global empirical framework within the hydrological community (Donohue et al. 2011; Coron et al. 2015: Greve et al. 2015). This method relates the interannual evaporative index (ratio between actual evapotranspiration and precipitation) and the interannual dryness index (ratio between potential evapotranspiration and precipitation) in a global description called the "Budyko space." Thereby, all interactions through the hydrological cycle between vegetation, soil, and atmosphere create an empirical equilibrium represented by the Budyko curve (van der Velde et al. 2013). To emphasize the impact of other factors on the water balance such as vegetation, an emerging general relationship proposed by Zhang et al. (2001) known as the Budyko-Zhang framework has been used. This empirical framework comes from an evaluation of 250 catchments worldwide including dryland regions (Zhang et al. 2001). It has been applied to single catchments and specific areas until nowadays, considering different approaches as the assessing of their sensitivity to climate change (Donohue et al. 2011; Renner and Bernhofer 2012; van der Velde et al. 2013). In order to answer properly the issues raised by the effects of climate change on water resources (Sivapalan et al. 2011), the Budyko curve is recognized "as a much valuable tool to back to the basics, it means, the physical basis of catchment water balance" (Coron et al. 2015).

The degree of anthropogenic influence can be determined using two types of influence on runoff change: human activity with direct influence (soil conservation, water control works, increasing water demand) and human activity with indirect influence (land use and land cover changes) (Wang et al. 2013). They constitute descriptive elements to understand the behavior of hydroclimatic data series at interannual scale and to identify the catchments presenting a low level of anthropogenization. This selection can be performed through an analysis of water balance disparity by catchment via the Budyko-Zhang framework, which assumes that catchments do not present changes in basin water storage over long-term averages ( $\geq 10$ years) (Zhang et al. 2001). This steady-state assumption is related to a closed land water balance, which is expected to maintain over catchments with a low water balance disparity.

This study aims at explaining the hydroclimatic behavior of the $\mathrm{Pd}$ catchments as a benchmark for understanding the sensitivity of catchments to changes in water balance along this region having a large latitudinal extent with a steep topography in the longitudinal direction. Firstly, a hydroclimatic complete description of the $\mathrm{Pd}$ is achieved based on the available time series of precipitation, temperature, evapotranspiration, and streamflow. Then, the Budyko-Zhang framework was applied to this dataset in order to identify catchments with a low (high) water balance disparity, which are associated with environments with less (more) climatic and human activity influence. Lastly, the use of Budyko space is considered for assessing the level of adaptation and sensitivity to climate variability and land use change.

\section{Study area}

The study area comprises the Peruvian Pacific drainage region $(\mathrm{Pd})$ that covers an area of $\sim 280,500 \mathrm{~km}^{2}$. This area is characterized by a significant altitudinal gradient ranging from 0 to $\sim 6500 \mathrm{~m}$ asl and includes 54 main river catchments covering nearly $90 \%$ of this region. The rivers generally flow from east to west from the Andes toward the Pacific Ocean (see Fig. 1) with bare and steep slopes from 4 to $9 \%$ within small and medium catchment areas from 500 to $16,000 \mathrm{~km}^{2}$ (see values in Table 1) that favor significant rising, flooding, and erosion during huge rainfall episodes. This region presents a large range of climate types from arid-tropical to tundra climate which results in altitudinal and latitudinal gradients in the climate conditions. While near the coast, dry climate conditions are heavily constrained by oceanic conditions that are characterized by a permanent upwelling south of $\sim 5^{\circ} \mathrm{S}$, the highlands experience more the influence from seasonal variations in the large-scale circulation patterns (i.e., Intertropical Convergence Zone, ITCZ) and the Southern Pacific Anticyclone (SPA). Also, at interannual timescale, anomalous rainfall events over the $\mathrm{Pd}$ are related to the El Niño Southern Oscillation (ENSO) (Rau et al. 2016).

The region under consideration concentrates more than $50 \%$ of the Peruvian population. Therefore, all catchments of $\mathrm{Pd}$ are characterized by recurrent conflicts about the water allocation between water uses located in arid lowlands ever since this region only benefits from $2 \%$ of the available freshwater in Peru. Water supply for human activities and consumption is about $80 \%$ of the national total and agriculture represents the greatest demand, which is based entirely on irrigation infrastructure systems because of little rainfall over arid lands (ANA 2012). This hydraulic infrastructure was built along main catchments since the beginning of the 1970s. This development implies the presence of ten large hydraulic systems with irrigation purposes (see their location and names in gray italic in Fig. 1b) and two systems mainly used for population 
Fig. 1 Location of the 26 studied catchments over the Peruvian Pacific drainage region: a location of hydrometeorological stations considered and land cover derived from MODIS data in 2008; b location of major cities and main large hydraulic infrastructures (names of hydraulic systems in italic gray) built between 1970 and 2008, and topography from SRTM digital elevation model
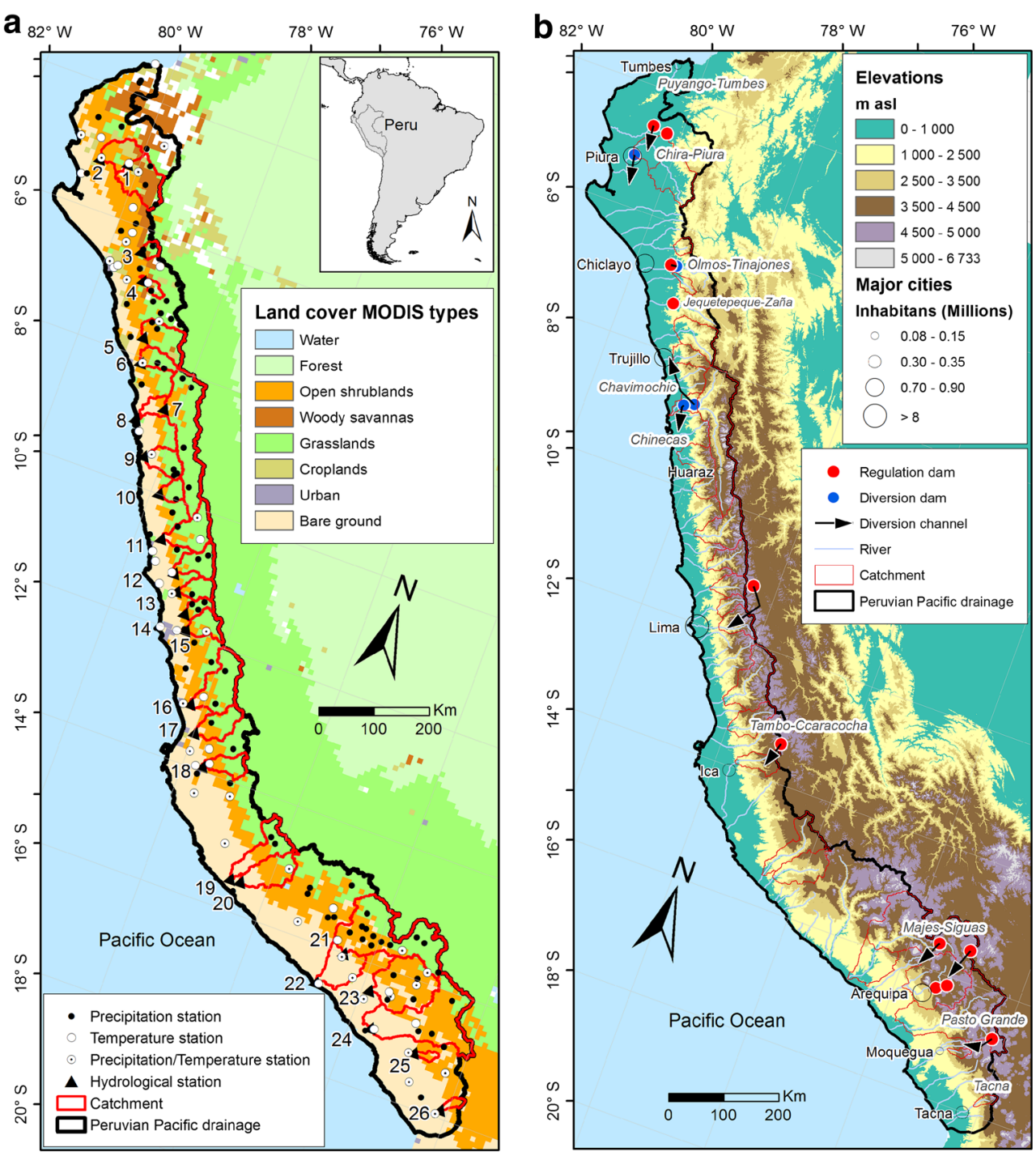

supply and hydroelectricity purposes for the major cities of Lima and Arequipa. Figure 1b shows the large hydraulic infrastructure predominant in the studied period, where one system can present only lake intakes and diversions (not shown for a reason of scale) as in the case of "Tacna" located around latitude $17.5^{\circ} \mathrm{S}$, present diversion channels only as in the case of "Chavimochic" and "Chinecas" located around latitude $9^{\circ} \mathrm{S}$, present two mega-reservoirs of 1000 and $250 \mathrm{Hm}^{3}$ capacity as in the case of "ChiraPiura" located around latitude $5^{\circ} \mathrm{S}$, and present only one mega-reservoir as the general case of around $300 \mathrm{Hm}^{3}$ capacity. These mega-reservoirs are located in highlands and midlands, and diversion channels are responsible in many cases of huge water transfer from the Atlantic to the Pacific drainage basins (see Fig. 1b for the cities of Lima and Ica). However, in some cases, this infrastructure has an influence restricted to areas located downstream of the hydrological stations and does not have relevant impacts over the water balance upstream of these stations.

\section{Data}

\subsection{Hydroclimatic dataset and validation}

The database covers the 1970-2008 period and includes monthly precipitation, temperature, and streamflow observations. Precipitation series were obtained from 139 pluviometric stations, temperature series from 59 meteorological stations, and monthly streamflow from 35 hydrological stations (see Fig. 1a) managed by the SENAMHI (National Meteorological and Hydrological Service of Peru).

A careful quality check of these data was performed as follows: monthly precipitation data were previously homogenized and validated in this region (see Bourrel et al. 2015 and Rau et al. 2016 for details about the processing). Mean monthly temperature data were homogenized and validated following Lavado et al. (2013). Missing values were filled by monthly average and by a multiple correlation method based on nearby geographical station data. Monthly streamflow data were 
Table 1 General characteristics of the 26 studied catchments at their outlets gauging stations for the 1970-2008 period

\begin{tabular}{|c|c|c|c|c|c|c|c|c|c|c|}
\hline No. & Catchment & $\begin{array}{l}\text { Gauging } \\
\text { station }\end{array}$ & $\begin{array}{l}\text { Lat } \\
{ }^{\circ} \mathrm{S}\end{array}$ & $\begin{array}{l}\text { Long } \\
{ }^{\circ} \mathrm{W}\end{array}$ & $\begin{array}{l}A \\
\left(\mathrm{~km}^{2}\right)\end{array}$ & $\begin{array}{l}\text { Min } \\
\text { alt (m } \\
\text { asl) }\end{array}$ & $\begin{array}{l}\text { Max } \\
\text { alt (m } \\
\text { asl) }\end{array}$ & $\begin{array}{l}S \\
(\%)\end{array}$ & $\begin{array}{l}Q \\
\left(\mathrm{~m}^{3} /\right. \\
\mathrm{s})\end{array}$ & $\begin{array}{l}\text { Qsp } \\
(1 / \mathrm{s} / \\
\left.\mathrm{km}^{2}\right)\end{array}$ \\
\hline 1 & Piura up & Pte. Ñacara & 5.11 & 80.17 & 4762 & 119 & 3526 & 5.7 & 27.4 & 5.7 \\
\hline 2 & Piura & $\begin{array}{l}\text { Pte. Sanchez } \\
\text { Cerro }\end{array}$ & 5.18 & 80.62 & 7622 & 23 & 3547 & 3.6 & 51.3 & 6.7 \\
\hline 3 & La Leche & Puchaca & 6.38 & 79.47 & 771 & 355 & 3982 & 9.3 & 6.1 & 7.9 \\
\hline 4 & Zaña & Batan & 6.8 & 79.29 & 664 & 260 & 3799 & 7.9 & 7.7 & 11.6 \\
\hline 5 & Chicama & Salinar & 7.67 & 78.97 & 3684 & 350 & 4217 & 8.5 & 24.7 & 6.7 \\
\hline 6 & Moche & Quirihuac & 8.08 & 78.87 & 1883 & 200 & 4238 & 9.2 & 8.1 & 4.3 \\
\hline 7 & Santa up & Condorcerro & 8.65 & 78.25 & 1041 & 450 & 6567 & 8.1 & 142.2 & 13.7 \\
\hline 8 & Santa & $\begin{array}{l}\text { Pte. } \\
\text { Carretera }\end{array}$ & 8.97 & 78.63 & 1166 & 18 & 6567 & 7.7 & 200.1 & 17.2 \\
\hline 9 & Casma & $\begin{array}{l}\text { Sector } \\
\text { Tutuma }\end{array}$ & 9.48 & 78.3 & 2567 & 71 & 4769 & 9.1 & 6.1 & 2.4 \\
\hline 10 & Huarmey & $\begin{array}{l}\text { Puente } \\
\text { Huamba }\end{array}$ & 9.97 & 77.87 & 1329 & 555 & 4742 & 8.3 & 5.4 & 4.0 \\
\hline 11 & Pativilca & Yanapampa & 10.67 & 77.58 & 4196 & 800 & 5941 & 8.4 & 41.6 & 9.9 \\
\hline 12 & Huaura & Sayan & 11.12 & 77.18 & 2893 & 650 & 5348 & 7.0 & 28.1 & 9.7 \\
\hline 13 & $\begin{array}{l}\text { Ch. } \\
\text { Huaral }\end{array}$ & $\begin{array}{l}\text { Santo } \\
\text { Domingo }\end{array}$ & 11.38 & 77.05 & 1856 & 697 & 5122 & 7.7 & 17.8 & 9.6 \\
\hline 14 & Chillon & Larancocha & 11.68 & 76.8 & 1207 & 1200 & 5099 & 8.6 & 6.3 & 5.2 \\
\hline 15 & Rimac & Chosica & 11.93 & 76.69 & 2352 & 906 & 5370 & 7.2 & 31.5 & 13.4 \\
\hline 16 & Cañete & Socsi & 13.03 & 76.2 & 5845 & 330 & 5632 & 6.7 & 54.5 & 9.3 \\
\hline 17 & San Juan & Conta & 13.45 & 75.98 & 3057 & 350 & 5049 & 6.9 & 11.5 & 3.8 \\
\hline 18 & Ica & La Achirana & 13.97 & 75.68 & 2119 & 500 & 4591 & 5.7 & 7.2 & 3.4 \\
\hline 19 & Acari & Bella Union & 15.48 & 74.63 & 4242 & 70 & 4620 & 6.1 & 12.4 & 2.9 \\
\hline 20 & Yauca & Puente Jaqui & 15.48 & 74.45 & 4140 & 214 & 4923 & 6.8 & 9.7 & 2.3 \\
\hline 21 & Majes & Huatiapa & 16.0 & 72.47 & 13,414 & 699 & 6300 & 5.4 & 85.5 & 6.4 \\
\hline 22 & Camana & Pte. Camana & 16.6 & 72.73 & 16,238 & 122 & 6300 & 5.4 & 70.7 & 4.4 \\
\hline 23 & Chili & $\begin{array}{l}\text { Puente del } \\
\text { diablo }\end{array}$ & 16.42 & 71.87 & 8393 & 2360 & 5954 & 4.3 & 13.3 & 1.6 \\
\hline 24 & Tambo & Chucarapi & 16.99 & 71.64 & 13,063 & 281 & 5554 & 5.0 & 33.9 & 2.6 \\
\hline 25 & Moquegua & Chivaya & 17.13 & 70.83 & 469 & 2000 & 5279 & 5.8 & 1.0 & 2.0 \\
\hline 26 & Caplina & $\begin{array}{l}\text { Aguas } \\
\text { Calientes }\end{array}$ & 17.85 & 70.12 & 548 & 130 & 5522 & 7.7 & 0.8 & 1.5 \\
\hline
\end{tabular}

Lat: latitude; Long: longitude; A: drainage area; Min alt: minimum altitude; Max alt: maximum altitude; S: mean slope; mean annual values of $Q$ : streamflow; $Q s p$ : specific runoff homogenized and validated considering the approaches of regionalization between neighboring catchments (Lavado et al. 2012). Missing values (less than $5 \%$ of total) were filled by monthly average.

Precipitation and temperature data were interpolated to a $5 \times 5-\mathrm{km}$ grid using the inverse distance weighting technique. Orographic effects on precipitation and temperature were accounted for using the SRTM digital elevation model in a similar way as described in Ruelland et al. (2014). These effects on precipitation were considered using the approach proposed by Valéry et al. (2010) with a correction factor of $4 \times 10^{-4} \mathrm{~m}^{-1}$ (estimated from the observed data), which corresponds to a $20 \%$ increase in local precipitation with an elevation of $500 \mathrm{~m}$. Temperature was interpolated by accounting for a constant lapse rate of $-6.5^{\circ} \mathrm{C} / \mathrm{km}$ (estimated from the observed data). Finally, since the only data available for calculating potential evapotranspiration (PET) were temperature data, a formula relying on clear monthly sky solar radiation and mean monthly air temperature was selected (Oudin et al. 2005):

$$
\begin{gathered}
\text { PET }=\frac{R_{\mathrm{e}}}{\lambda \rho} \frac{T+K_{2}}{K_{1}} \text { if } T+K_{2}>0 \\
\text { PET }=0, \text { otherwise }
\end{gathered}
$$

where PET is the rate of potential evapotranspiration ( $\mathrm{mm} /$ day), $R_{\mathrm{e}}$ is the extraterrestrial radiation $\left(\mathrm{MJ} / \mathrm{m}^{2} /\right.$ day), $\lambda$ is the latent heat flux $(2.45 \mathrm{MJ} / \mathrm{kg}), \rho$ is the density of water $\left(\mathrm{kg} / \mathrm{m}^{3}\right), T$ is the mean daily air temperature $\left({ }^{\circ} \mathrm{C}\right)$, and $K_{1}$ and $K_{2}$ are fitted parameters (for a general case: $K_{1} \sim 100$ and $K_{2} \sim 5$ ). 
Equation 1 was applied at monthly time step. The Oudin formula is a temperature-based evapotranspiration model, which is adapted to arid and semiarid regions limited by scarcity of in situ climate data (see, e.g., Hublart et al. 2015, 2016). Indeed, Oudin et al. (2005) showed that from an operational point of view, this model is as efficient as more complex models such as the Penman model and its variants.

Finally, we restricted our analysis to 26 catchments (see Fig. 1a) characterized by a valuable and confident complete dataset of monthly precipitation, temperature, and streamflow series over 1970-2008.

\subsection{Land cover data and digital elevation model}

Four land cover maps based on remotely sensed images acquired between 1984 and 2008 were used in this study. They are based on multispectral images from different sensors with a spatial resolution increasing against time. The LBA (Large Scale Biosphere-Atmosphere Experiment in Amazonia) Regional Land Cover products for 1984 (DeFries et al. 1998; $8 \times 8 \mathrm{~km}$ grid) and 1992/1993 (Hansen et al. 2000; $1 \times 1 \mathrm{~km}$ grid) were derived from acquisitions from the Advanced Very High Resolution Radiometer (AVHRR) for comparative purposes. The land covers of 2001 and 2008 were derived from acquisitions from the Moderate Resolution Imaging Spectroradiometer (MODIS). These products, made available by the Global Land Cover Facility (GLCF, http://glcf.umd.edu/data/lc) on $10 \times 10 \mathrm{~km}$ grid, have a spatial resolution of $5^{\prime}$. The land cover map used in Fig. 1a is the MODIS land cover type for 2008. They show that the $\mathrm{Pd}$ region is characterized mainly by four types of land cover: bare ground, open shrublands, grasslands, and croplands. These different types of vegetation are directly related to the different climates observed in the Pd region.

The digital elevation model shown in Fig. 1b was obtained from the $90 \times 90-m$ grid SRTM data (Shuttle Radar Topography Mission, NASA-NGA, USA available from http://srtm.csi.cgiar.org). It allowed the orographic corrections to be applied for the climate forcing interpolation (see Section 3.1) and the 26 main river catchments located in the $\mathrm{Pd}$ to be delineated (catchment numbering and parameters are shown in Table 1).

\section{Methods}

The methodology consists of three steps:

(a) Evaluation of hydroclimatic time series

(b) Evaluation of the catchment water balance disparity via the Budyko-Zhang framework. Selection of catchments with low disparity (c) Analysis of the hydroclimatic change disparity of selected catchments using trajectories in Budyko space

\subsection{Evaluation of hydroclimatic time series}

After compiling all datasets by catchment, complementary analyses were performed for detecting plausible trends and changes using the nonparametric Mann-Kendall trend test, the double mass curve method, and the Pettitt test.

The rank-based Mann-Kendall test (Mann 1945; Kendall 1975) was used to detect trends in the hydroclimatic series. The method is recommended by the World Meteorological Organization (WMO) and widely used for assessing the significance of monotonic trends in hydrological series. This method does not infer any distributional function for the data and has already proven its efficiency (e.g., Lavado et al. 2012; Chen et al. 2013; Wang et al. 2013). The double mass curve consists of the plot of the accumulated values of one variable versus the accumulated values of another related variable for the same period (Searcy and Hardison 1960). The plot is a straight line if the two variables are proportional, and the slope of this line represents the ratio between the two variables. A change in the gradient of the curve indicates that the original relationship between variables was modified. It can be used to check the consistency of hydrological records and has recently become an effective tool for detecting the changes of hydrological regime due to anthropogenic disturbances (e.g., Zhang and Lu 2009; Wang et al. 2013). In this study, a double mass curve between precipitation and runoff was employed as an auxiliary confirmation of the change points when catchment changes mainly induced by human activities exert influences on the river.

The Pettitt test (Pettitt 1979) is a nonparametric approach to determine the occurrence of a change point. This approach is a rank-based and distribution-free test for detecting a significant change in the mean of a time series when the exact time of the change is unknown. Pettitt test has been widely used to detect changes in the hydroclimatic records (e.g., Lavado et al. 2012; Wang et al. 2013). We used the Pettitt test to identify the change point of the runoff series and compare with the change points detected by double mass curve.

\subsection{Catchment water balance disparity}

The water balance for a catchment can be basically described in a general form at annual scale as:

$P=\mathrm{AET}+R+\Delta S$

where $P$ is precipitation ( $\mathrm{mm} /$ year), AET is the actual evapotranspiration (mm/year), $R$ is runoff ( $\mathrm{mm} /$ year), and $\Delta S$ is the change in basin water storage (mm/year). At the annual scale, 
$\Delta S$ can be neglected especially for long periods ( $\geq 10$ years) (Zhang et al. 2001).

Based on the Budyko theory (Budyko 1974) which considers that the available energy and water are the primary factors for determining the rate of actual evapotranspiration, we used here the approach developed by Zhang et al. (2001). It was called the Budyko-Zhang curve, which estimates the AET based on a simple model (see Eq. 3) that is written as follows:

$$
\frac{\mathrm{AET}}{P}=\frac{1+w\left(\frac{\mathrm{PET}}{P}\right)}{1+w\left(\frac{\mathrm{PET}}{P}\right)+\frac{P}{\mathrm{PET}}}
$$

where PET (mm/year) is the potential evapotranspiration and $w$ (nondimensional) is the plant-available water coefficient related to vegetation type. The details of the relationship can be found in Zhang et al. (2001). The very sensitive parameter $w$ is calibrated over the long-term interannual AET from Eq. 3. The use of the Budyko-Zhang curve over the Pd appears as a valuable method for the interpretation of the water balance considering the importance of vegetation (Donohue et al. 2007) over arid and semiarid areas. It has been used previously in comparable studies such as Yang et al. (2009), Zhao et al. (2013), and Chen et al. (2013).

Low disparity of a water balance was evaluated in terms of three criteria: (a) the shape of the association of points between dryness index (PET/P) and evaporative index (AET/ $P$ ), which must follow a Budyko-Zhang curve with a positive value of $w$; (b) the correlation coefficient $r$ between the AET estimated using the Budyko-Zhang framework and estimated using the water balance $(P-R)$ which must be higher than 0.7 ; and (c) the relative standard error (\%RSE) from the curve adjustment which should be less than $15 \%$. Any catchment outside these three criteria falls off the Budyko curve and is considered as a catchment with a high water balance disparity. According to Wang and Hejazi (2011), Jones et al. (2012), and Coron et al. (2015), such a catchment is interpreted as being strongly influenced by anthropogenization, a catchment under strong climatic variability conditions especially droughts, a catchment with other missing components of water balance (such as water demands, groundwater flow alteration), or in the worst case, a catchment where there were inadequate measures of the hydroclimatic variables.

\subsection{Hydroclimatic change disparity}

Based on Jones et al. (2012), under stationary conditions or natural climatic oscillations, catchments should fall on the Budyko curve. Under nonstationary conditions or anthropogenic climate change, catchments are likely to deviate from the Budyko curve in a predictable manner. Over these conditions and following van der Velde et al. (2013) and Jaramillo and Destouni (2014), the trajectories in Budyko space were defined, which are characterized by a direction $(\alpha)$ and magnitude $(\beta)$ of change over the considered period. The direction of change is calculated from the equation:

$\alpha=\arctan \left[\frac{\Delta \mathrm{AET} \cdot(P)-(\mathrm{AET}) \cdot \Delta P}{\Delta \mathrm{PET} \cdot(P)-(\mathrm{PET}) \cdot \Delta P}\right]$

where AET (mm/year) is the average AET over the period, and $\triangle$ AET $\left(\mathrm{mm} / \mathrm{year}^{2}\right)$ is the change of AET over the period. Also, PET (mm/year), $\triangle$ PET (mm/year $\left.{ }^{2}\right), P(\mathrm{~mm} /$ year), and $\Delta P\left(\mathrm{~mm} / \mathrm{year}^{2}\right)$ are the average PET and change of PET over the period, the average $P$, and change of $P$ over the period, respectively. Here, $\alpha$ is calculated in degrees and counterclockwise from the negative $y$-axis. In the same way, the magnitude of change is expressed as the following equation and expressed in $1 /$ year.

$\beta=\sqrt{\left(\frac{\Delta \mathrm{AET} \cdot(P)-(\mathrm{AET}) \cdot \Delta P}{(P)^{2}}\right)^{2}+\left(\frac{\Delta \mathrm{PET} \cdot(P)-(\mathrm{PET}) \cdot \Delta P}{(P)^{2}}\right)^{2}}$

Direction is related to change adaptations of ecosystems and magnitude related to ecosystem sensitivity to climate variability and land use change.

\section{Results and discussion}

\subsection{Hydroclimatic time series}

Based on the processing of the original monthly time step database, a complete monthly hydroclimatic dataset of precipitation $(P)$, temperature $(T)$, potential evapotranspiration (PET), and streamflow $(Q)$, over the 1970-2008 period, was computed, for each of the 26 catchments in a lumped way. The series of annual PET, annual runoff $(R)$ by the ratio between $Q$ and catchment area, and annual actual evapotranspiration (AET) by water balance $(P-R)$ following the hydrological year (September-August) were determined. Observed annual $P$, estimated PET, and $R$ series from 11 catchments (mostly covering the 1970-2008 period) are presented for displaying purposes in Fig. 2 (the choice of these 11 catchments among the whole of our 26 studied catchments is discussed in Section 5.2).

Mean annual values of hydroclimatic series are given in Table 2. For mean annual precipitation, catchments located in northern areas generally present higher values above $600 \mathrm{~mm} /$ year than southern areas with values under around $400 \mathrm{~mm} /$ year. This is because of the influence of the ENSO phenomenon over northern catchments that clearly appears in 
Fig. 2 a-k Long-term variations of annual mean time series of precipitation $(P)$, potential evapotranspiration (PET), and runoff $(R)$ for 11 selected catchments over the 1970-2008 period
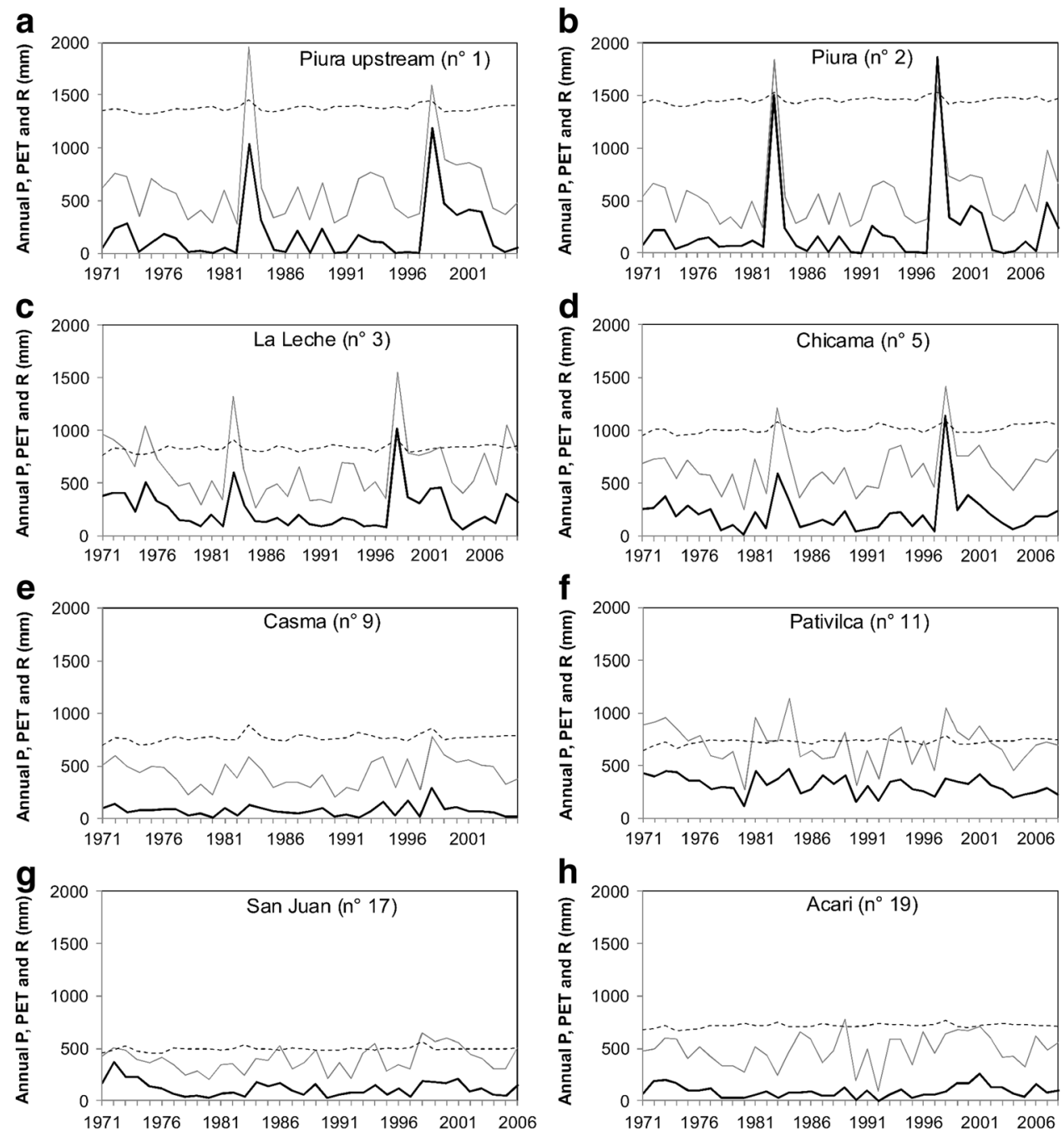

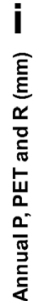
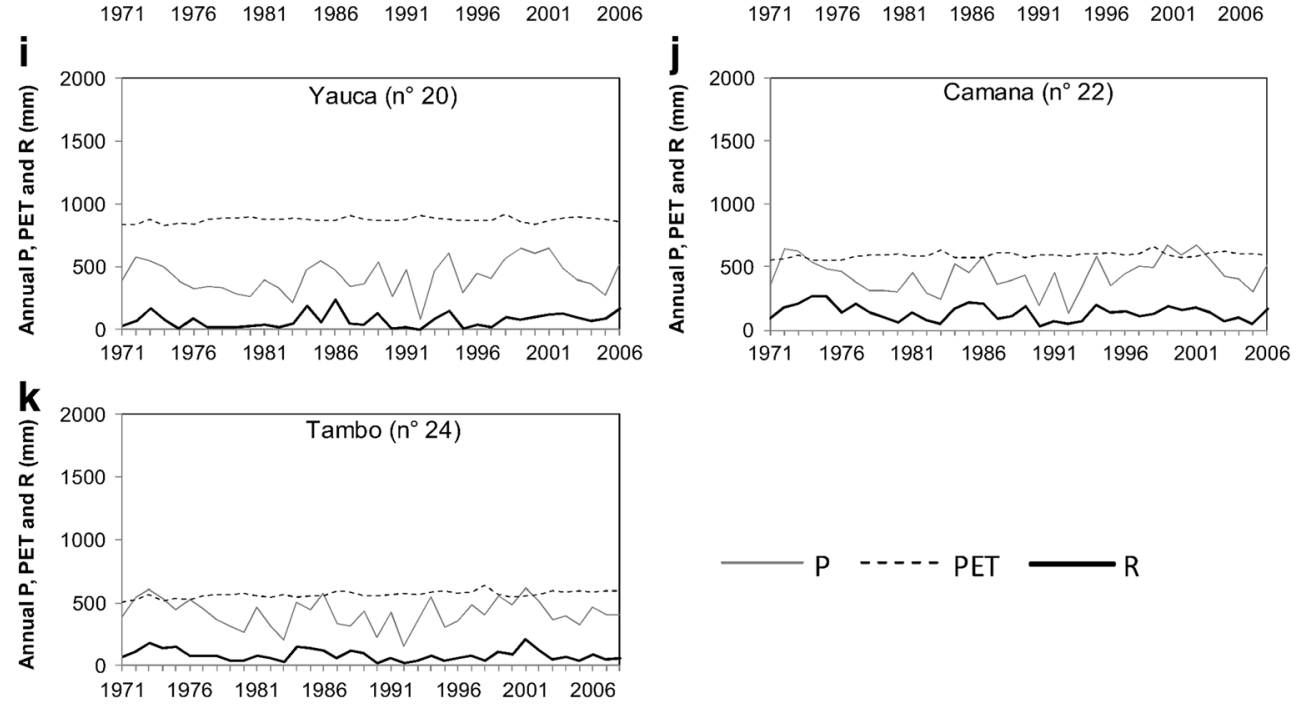

peaks during 1982/1983 and 1997/1998 events known as years of extreme El Niño events (see Fig. 2a-d). This influence is also present in the runoff variability, decreasing toward southern latitudes in general, but showing high values above
$400 \mathrm{~mm} /$ year in catchments located at central areas such as Santa upstream (no. 7), Santa (no. 8), and Rimac (no. 15), associated with the relationship of water availability and catchment size. For mean annual temperature, PET, and 
Table 2 Hydroclimatic conditions over the 1970-2008 period and 2008 land cover types in the 26 studied catchments. Mean annual values of precipitation $(P)$, temperature $(T)$, potential evapotranspiration (PET), actual evapotranspiration (AET), runoff $(R)$, and aridity index (P/PET). Land cover percentage from MODIS (2008) of open shrubland (OS), grasslands (GL), croplands (CL), and bare ground (BG)

\begin{tabular}{|c|c|c|c|c|c|c|c|c|c|c|c|c|}
\hline No. & Catchment & Gauging station & $\begin{array}{l}P \\
(\mathrm{~mm} / \text { year })\end{array}$ & $\begin{array}{l}T \\
\left({ }^{\circ} \mathrm{C} / \text { year }\right)\end{array}$ & $\begin{array}{l}\text { PET } \\
(\mathrm{mm} / \text { year })\end{array}$ & $\begin{array}{l}\text { AET } \\
(\mathrm{mm} / \text { year })\end{array}$ & $\begin{array}{l}R \\
\text { (mm/year) }\end{array}$ & $P / \mathrm{PET}$ & OS $(\%)$ & GL $(\%)$ & CL (\%) & $\mathrm{BG}(\%)$ \\
\hline 1 & Piura up & Pte. Ñacara & 613 & 20 & 1376 & 432 & 181 & 0.45 & 27 & 11 & 13 & 0 \\
\hline 2 & Piura & Pte. Sanchez Cerro & 551 & 22 & 1456 & 355 & 212 & 0.38 & 34 & 12 & 20 & 0 \\
\hline 3 & La Leche & Puchaca & 640 & 10 & 831 & 391 & 249 & 0.77 & 0 & 75 & 0 & 0 \\
\hline 4 & Zaña & Batan & 817 & 12 & 933 & 450 & 367 & 0.88 & 0 & 50 & 12 & 0 \\
\hline 5 & Chicama & Salinar & 643 & 14 & 1013 & 432 & 211 & 0.63 & 23 & 69 & 4 & 2 \\
\hline 6 & Moche & Quirihuac & 645 & 8 & 703 & 509 & 136 & 0.92 & 26 & 74 & 0 & 0 \\
\hline 7 & Santa up & Condorcerro & 936 & 2 & 400 & 505 & 431 & 2.34 & 13 & 86 & 0 & 1 \\
\hline 8 & Santa & Pte. Carretera & 854 & 3 & 473 & 381 & 541 & 1.80 & 17 & 76 & 0 & 7 \\
\hline 9 & Casma & Sector Tutuma & 430 & 9 & 769 & 354 & 75 & 0.56 & 10 & 63 & 0 & 27 \\
\hline 10 & Huarmey & Puente Huamba & 580 & 6 & 576 & 453 & 127 & 1.01 & 14 & 86 & 0 & 0 \\
\hline 11 & Pativilca & Yanapampa & 700 & 8 & 728 & 387 & 313 & 0.96 & 14 & 82 & 0 & 4 \\
\hline 12 & Huaura & Sayan & 654 & 3 & 444 & 348 & 307 & 1.47 & 9 & 91 & 0 & 0 \\
\hline 13 & Ch. Huaral & Santo Domingo & 579 & 1 & 341 & 286 & 303 & 1.70 & 9 & 91 & 0 & 0 \\
\hline 14 & Chillon & Larancocha & 555 & 2 & 370 & 390 & 165 & 1.50 & 23 & 77 & 0 & 0 \\
\hline 15 & Rimac & Chosica & 646 & 3 & 436 & 224 & 422 & 1.48 & 19 & 81 & 0 & 0 \\
\hline 16 & Cañete & Socsi & 556 & 1 & 339 & 261 & 294 & 1.64 & 20 & 74 & 0 & 6 \\
\hline 17 & San Juan & Conta & 393 & 4 & 496 & 274 & 119 & 0.79 & 32 & 63 & 0 & 5 \\
\hline 18 & Ica & La Achirana & 432 & 5 & 554 & 325 & 107 & 0.78 & 38 & 58 & 0 & 4 \\
\hline 19 & Acari & Bella Union & 486 & 8 & 715 & 394 & 92 & 0.68 & 23 & 51 & 0 & 26 \\
\hline 20 & Yauca & Puente Jaqui & 422 & 11 & 873 & 348 & 74 & 0.48 & 50 & 25 & 0 & 25 \\
\hline 21 & Majes & Huatiapa & 537 & 3 & 430 & 336 & 201 & 1.25 & 35 & 59 & 0 & 6 \\
\hline 22 & Camana & Pte. Camana & 441 & 6 & 593 & 303 & 137 & 0.74 & 28 & 47 & 1 & 24 \\
\hline 23 & Chili & Pte. del diablo & 370 & 5 & 556 & 320 & 50 & 0.67 & 73 & 3 & 0 & 22 \\
\hline 24 & Tambo & Chucarapi & 418 & 6 & 566 & 336 & 82 & 0.74 & 50 & 12 & 0 & 38 \\
\hline 25 & Moquegua & Chivaya & 369 & 3 & 437 & 305 & 64 & 0.84 & 57 & 0 & 0 & 43 \\
\hline 26 & Caplina & Aguas Calientes & 343 & 2 & 416 & 294 & 49 & 0.83 & 60 & 0 & 0 & 40 \\
\hline
\end{tabular}

AET, they decrease in general toward southern latitudes. Mean annual PET variability follows the same behavior of the mean annual temperature variability along the Pd because of the empirical nature of the Oudin method. However, there is a slight increase over arid catchment located in the south where there is a predominance of bare ground and open shrubland areas.

It is worth to mention that dryland regions encompass hyperarid, arid, semiarid, and dry subhumid areas (Brouwer and Heibloem 1986; Mortimore 2009), and these results corroborate the dryland conditions of the $\mathrm{Pd}$, accentuating toward southern latitudes. This can be explained by the range of the aridity index (P/PET) proposed by Hassan and Dregne (1997) and contrasted with the annual precipitation module, a method recommended by the United Nations Environment Program (UNEP). Table 2 provides the values of the aridity index in most of the catchments below "1" and precipitation below $1000 \mathrm{~mm}$ in all catchments. Southern catchments present an annual precipitation around below $400 \mathrm{~mm}$ and are defined as arid areas. Catchments located in major rainy areas (Santa up (no. 7), Santa (no. 8), Huarmey (no. 10), Huaura (no. 12), Chancay Huaral (no. 13), Chillon (no. 14), Rimac (no. 15), Cañete (no. 16), and Majes (no. 21)) are found in the limits between semiarid and dry subhumid areas. The rest of the catchments are defined as semiarid areas.

Changes in hydroclimatic series are presented in Table 3. An increase or a decrease (i.e., positive or negative sign, respectively) indicates the long-term behavior of the series. All slopes are significant at the 95\% level using Student's $t$ test; however, for highlighting the long-term effect of these hydroclimatic series over catchments, the trends and their significance (at the 95\% of confidence level) were estimated based on the Mann-Kendall test (significant trends are shown in bold in Table 3).

On the one hand, changes in runoff and precipitation are greater in northern catchments (mainly positive changes) and 
decrease toward southern latitudes. On the other hand, changes in $T$ and PET are always positive (see Table 3). This can be explained by regional climate anomalous conditions along the $\mathrm{Pd}$, in particular the well-known ENSO influence over precipitation and runoff in the northern areas (Lavado et al. 2012; Bourrel et al. 2015; Rau et al. 2016). Trend tests indicate that a long-term increase in temperature time series is significant in all catchments with a mean value of $+0.02^{\circ} \mathrm{C} /$ year $^{2}(\sim$ a mean warming of $0.2{ }^{\circ} \mathrm{C}$ per decade). There is an area covering Moche (no. 6) and Santa up (no. 7) catchments with a mean warming above of $0.3{ }^{\circ} \mathrm{C}$ per decade. This is consistent with previous climatological studies for the Andes such as the one by Vuille et al. (2015) that showed that most stations over the Pd had a significant positive trend in total temperature with a mean warming above of $0.2{ }^{\circ} \mathrm{C}$ per decade. They suggested that at inland and higher elevation locations, there is a clear evidence of warming, and in coastal regions, there is still a regional climate influence due to the variability of the Pacific Decadal Oscillation (PDO) and of the intensity of the South Pacific Anticyclone (SPA). Our results support the interpretation of warming at basin scale (i.e., the influence of either global warming or climate variability at timescales longer than the PDO) where these changes in temperature are expected to have important consequences for western Andean glaciers.

No significant increase or decrease in $P$ was observed over the study area (except only for Piura (no. 2) catchment). The $R$ time series present a significant increase over Ica (no. 18) which is related to water transfers from the Atlantic basin (see Fig. 1b) and over Yauca (no. 20) related with the no significant increase in PET. Runoff also presents a significant decrease over central catchments (Santa up no. 7, Pativilca no. 11, and Huaura no. 12) whose upper basins benefit from the melting of the Cordillera Blanca glacier and surroundings. At

Table 3 Mean annual change $(\Delta)$ in precipitation $(P)$, temperature $(T)$, potential evapotranspiration (PET), actual evapotranspiration (AET), and runoff $(R)$. Values with significant trends at $95 \%$ of confidence level are shown in bold. Years of significant change point at $95 \%$ of confidence level are indicated between parentheses

\begin{tabular}{|c|c|c|c|c|c|c|c|c|c|}
\hline No. & Catchment & $\Delta P\left(\mathrm{~mm} /\right.$ year $\left.^{2}\right)$ & $\Delta T\left({ }^{\circ} \mathrm{C} /\right.$ year $^{2}$ & $\Delta$ PET $\left(\mathrm{mm} /\right.$ year $\left.^{2}\right)$ & $\Delta$ AET $\left(\mathrm{mm} /\right.$ year $\left.^{2}\right)$ & $\Delta R\left(\mathrm{~mm} /\right.$ year $\left.^{2}\right)$ & $w$ & $r$ & $\operatorname{RSE}(\%)$ \\
\hline 1 & Piura up & 2.84 & $\mathbf{0 . 0 2}(1986)$ & $1.20(1986)$ & -1.36 & 4.20 & 0.25 & 0.85 & 4 \\
\hline 2 & Piura & 3.95 (1997) & $\mathbf{0 . 0 2}(1986)$ & $0.98(1986)$ & 1.11 & 3.28 & 0.03 & 0.79 & 2 \\
\hline 3 & La Leche & 0.18 & 0.02 & 1.10 & 1.07 & -0.90 & 0.18 & 0.88 & 5 \\
\hline 4 & Zaña & $5.19(1982)$ & 0.01 & 0.73 & $4.00(1983)$ & 1.19 & 0.00 & 0.67 & 7 \\
\hline 5 & Chicama & 3.31 & $\mathbf{0 . 0 3}(1982)$ & $1.71(1982)$ & 3.15 (1992) & 0.16 & 0.32 & 0.83 & 5 \\
\hline 6 & Moche & 1.46 & 0.06 & 3.11 & 0.61 & 0.85 & 2.59 & 0.85 & 28 \\
\hline 7 & Santa up & $3.80(1992)$ & $\mathbf{0 . 0 4}(1991)$ & 2.12 (1996) & 7.28 (1992) & -3.48 & 3.61 & 0.84 & 135 \\
\hline 8 & Santa & 2.43 & 0.03 & 1.41 & 4.15 (1992) & -1.97 & -0.58 & 0.56 & 33 \\
\hline 9 & Casma & 1.31 & $\mathbf{0 . 0 3}(1990)$ & $1.53(1982)$ & $1.44(1992)$ & -0.13 & 1.16 & 0.95 & 8 \\
\hline 10 & Huarmey & 4.77 & $\mathbf{0 . 0 3}(1982)$ & 1.75 (1982) & 2.76 & 2.01 & 3.12 & 0.85 & 40 \\
\hline 11 & Pativilca & -2.90 & 0.02 & 1.08 & 0.33 & - $3.22(1989)$ & 0.02 & 0.91 & 6 \\
\hline 12 & Huaura & -2.70 & 0.02 & 1.19 (1996) & 0.45 & - $\mathbf{3 . 1 5}(1987)$ & 0.78 & 0.71 & 32 \\
\hline 13 & Ch. Huaral & -0.33 & $\mathbf{0 . 0 3}(1996)$ & 1.13 (1996) & 2.40 & -2.78 & 0.65 & 0.64 & 48 \\
\hline 14 & Chillon & -0.43 & $\mathbf{0 . 0 3}(1996)$ & $1.58(1991)$ & -1.45 & 1.02 & 4.08 & 0.81 & 101 \\
\hline 15 & Rimac & -1.08 & $\mathbf{0 . 0 3}(1991)$ & $1.48(1991)$ & -2.71 & 1.63 & -0.49 & 0.67 & 11 \\
\hline 16 & Cañete & 2.80 & 0.01 & 0.30 & 4.24 (1996) & -1.44 & 0.27 & 0.66 & 35 \\
\hline 17 & San Juan & 2.38 & 0.01 & 0.55 & 3.77 (1992) & -1.39 & 0.73 & 0.77 & 12 \\
\hline 18 & Ica & 2.43 & $\mathbf{0 . 0 2}(1979)$ & $\mathbf{0 . 8 4}(1991)$ & 1.17 & $1.26(1993)$ & 1.20 & 0.92 & 15 \\
\hline 19 & Acari & 2.70 & 0.01 (1977) & 0.75 (1977) & 2.43 & 0.26 & 1.61 & 0.93 & 14 \\
\hline 20 & Yauca & 2.29 & 0.01 & 0.69 & 0.98 & 1.31 & 0.78 & 0.89 & 9 \\
\hline 21 & Majes & 1.53 & $\mathbf{0 . 0 3}(1986)$ & 1.34 (1986) & $2.72(1995)$ & -1.19 & 1.16 & 0.90 & 39 \\
\hline 22 & Camana & 1.23 & 0.02 (1986) & 1.13 (1986) & 2.75 (1995) & -1.52 & 0.47 & 0.88 & 9 \\
\hline 23 & Chili & 0.76 & $\mathbf{0 . 0 3}(1986)$ & $1.68(1986)$ & 0.23 & $0.53(1996)$ & 2.79 & 0.96 & 29 \\
\hline 24 & Tambo & -0.60 & $\mathbf{0 . 0 3}$ (1986) & 1.57 (1986) & 0.25 & -0.85 & 1.78 & 0.95 & 14 \\
\hline 25 & Moquegua & $-1.02(1977)$ & $\mathbf{0 . 0 3}(1982)$ & 1.47 (1982) & -0.90 & -0.12 & 3.55 & 0.98 & 46 \\
\hline 26 & Caplina & -0.75 & $\mathbf{0 . 0 2}(1982)$ & $\mathbf{0 . 8 5}(1982)$ & -1.12 & 0.37 (1996) & 4.30 & 0.97 & 53 \\
\hline
\end{tabular}

Catchments with low disparity in water balance are italicized

$w$ : Budyko-Zhang coefficient; $r$ : correlation coefficient between AET estimated by Budyko-Zhang and water balance; RSE: relative standard error from the curve adjustment 
interannual time step, these decreases could be mainly related to the intensive water exploitation for agricultural activities. AET time series present a significant increase in Zaña (no. 4), Chicama (no. 5), Santa up (no. 7), Cañete (no. 16), San Juan (no. 17), and Camana (no. 22) and a significant decrease in Rimac (no. 15) catchment.

Occurrence of change points at $95 \%$ of confidence level detected by the Pettitt test and double mass curve methods is significant in some catchments and the year when the change point occurred is indicated between parentheses in Table 3 . Most catchments did not present change points in $P$ (except Piura (no. 2), Zaña (no. 4), Santa up (no. 7), and Moquegua (no. 25)). Change points for $T$ time series were grouped by catchment proximity and regional localization along the Pd. For the northern catchments of Piura up (no. 1) and Piura (no. 2), the year of 1986 meant a change point. Catchments in southern latitudes present significant change points in the years 1977, 1982, and 1986. By the fact of presenting a warming on such a large scale, those change points could be related mainly by climatic influence (i.e., ENSO changes and climate shifts; see the work by Bourrel et al. 2015 for precipitation). Change points in $R$ are mainly related to the development of new phases into the large hydraulic infrastructure as in the case of Ica (no. 18), Chili (no. 23), and Caplina (no. 26) and also with the land cover change (which is discussed in the next section) as in the case of Pativilca (no. 11) and Huaura (no. 12).

\subsection{Catchment water balance disparity}

Based on the hydroclimatic time series calculated over the 26 catchments, we produced and analyzed series of dryness index $(\mathrm{PET} / P)$ and evaporative index $(\mathrm{AET} / P)$. Figure $3 \mathrm{a}, \mathrm{c}$ shows the dispersion of these two indices for two catchments (Piura upstream (no. 1) and Rimac (no. 15), respectively). Piura upstream shows the behavior of a northern catchment with strong climate variability as a result of ENSO influence, and Rimac shows the behavior of a very anthropized catchment as a result of large hydraulic infrastructure to provide water to the city of Lima (the capital of Peru) in the lowlands. Both catchments represent the two main types of associations found in the study area, which were differentiated following the methodology explained in Section 4.2 in terms of $w$ and "\%RSE" (i.e., see Fig. 3a, c) and $r$ (i.e., see Fig. 3b, d).

Figure 4 shows the dispersion of indices for all the 26 catchments, highlighting the two types of association (the low and high water balance disparity). The $w$ coefficients theoretically take values between 0.1 and 2 (Zhang et al. 2001) which are associated with the predominance of bare soils and forest, respectively (shown in Fig. 4 as constraints), even though some negative values on arid catchments were obtained by Chen et al. (2013). Our $w$ coefficient falls in the range of -0.58 to 4.30 and the best correlation coefficients $r$ and acceptable \%RSE are found with $w$ positive values in the range of 0.02 to 1.78 . That meant that only 11 catchments (italicized in Table 3) follow a "quasinatural" shape of the Budyko-Zhang curve, presenting a low disparity in water balance which can be related with low climatic and anthropogenic influence. The average of $w$ values is around 0.7 , indicating mean values for the plant-available water coefficient related to predominance of grasslands over the semiarid conditions of the Pd.

The 15 remaining catchments are represented by gray points in Fig. 4. Their AET/P values are located very near from the energy limit line (sometimes above the line) and far from the water limit line, which implies a complex combination of water losing systems (e.g., presence of open water surfaces, water lost to ground water system) with a nonnatural behavior of $P-R$ (see Eq. 2) affecting the AET calculation. Precipitation $(P)$ time series follows a natural behavior in all those catchments without strong trends or change points, suggesting that runoff $(R)$ has been altered. Also, those catchments are located mostly in an energy-limited environment $(\mathrm{PET} / P<1)$ where changes in $P$ and PET are likely more evident in $R$ (van der Velde et al. 2013), highlighting the strong climatic influence over $R$ in this type of environments as well as the anthropogenic influence due to the points outside the Budyko-Zhang curve.

The hypothesis about the anthropogenic effect as the main source of differentiation between catchments with high and low water balance disparity could not be easy to validate due to the difficult access or/and the scarcity of water use data. A complementary analysis of the evolution of the land cover in the study area was performed using the LBA 1984, LBA 1992/1993, MODIS 2001, and MODIS 2008 datasets (see Fig. 5). Even if improvements in resolution and data quality could impact estimates of spatial and temporal trends (from 10 to $1 \mathrm{~km}$ ), the temporal evolution of the classes suggests that catchments with high water balance disparity presented great changes over land cover conditions of cropland from 28 to $1 \%$ (from 1984 to 1992/1993) and grassland from 39 to 63\% (from 1992/1993 to 2001) as shown in Fig. 5a. These changes were not observed in catchments with low water balance disparity (excepting croplands from 39 to $7 \%$ from 1984 to 1992/1993). In addition, Fig. 5b shows the evolution of land cover over catchments grouped by latitudinal gradient and revealed that central catchments have a large change mainly in grassland cover from $40 \%$ to $75 \%$ (from 1992/1993 to 2001). It brings more confidence in northern and southern catchments, which presents certain homogeneity in the last decades.

About the influence of large hydraulic systems (see Fig. 1b), it is evident that some catchments with high disparity were influenced by those systems which transfer water from the Atlantic drainage (i.e., Rimac (no. 15) and Ica (no. 18)) 
Fig. 3 Comparison of two catchments with low (Piura up no. 1) and high (Rimac no. 15) water balance disparity according to the Budyko-Zhang framework. a, c Black lines represent the energy limit (diagonal) and the water limit (horizontal). b, d Scatter plot for correlation of annual AET obtained from water balance Eq. 2 and AET estimated by using Eq. 3

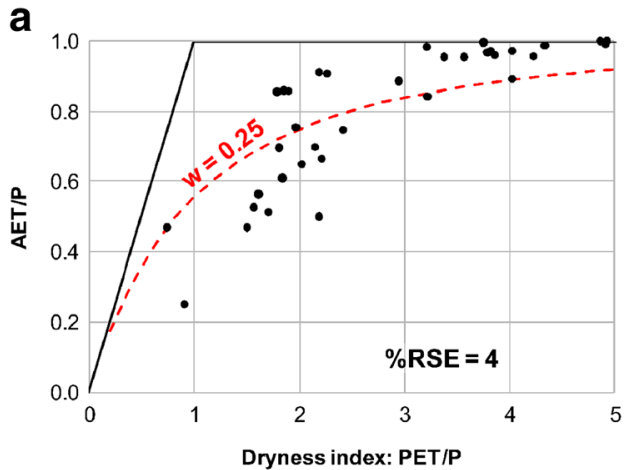

- Piura up $\left(n^{\circ} 1\right)---$ Budyko-Zhang adjustment

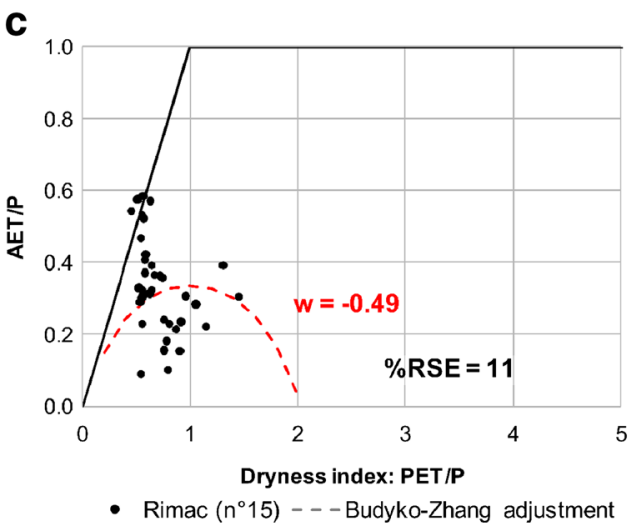

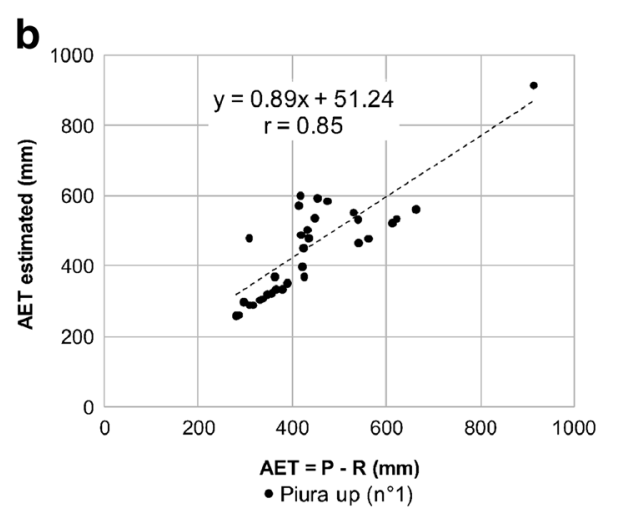

d

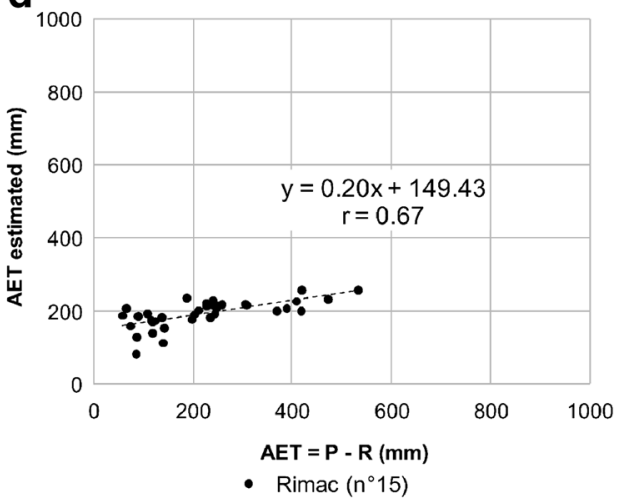

and by those which present large intakes and regulations for water supply in lower lands (Santa (no. 8), Majes (no. 21), and Chili (no. 23)). Also, there are some catchments with low water balance disparity that would still keep anthropogenic

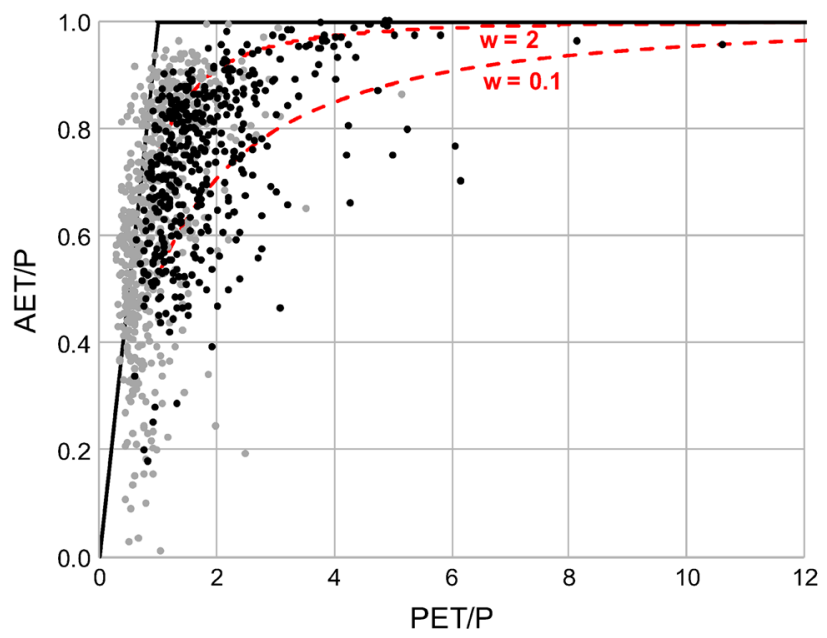

- High disparity - Low disparity - - - "w" theoretical limits

Fig. 4 Budyko space over the 1970-2008 period over the 26 studied catchments. The black lines represent the energy limit (horizontal) and the water limit (diagonal). Black (gray) points represent the association of yearly values from catchments showing a low (high) water balance disparity via the Budyko-Zhang framework. Red dashed curves represent the theoretical adjustment range for $w$ parameter $\left(w_{\min }=0.1\right.$; $w_{\max }=2$ ) effects according to Fig. 1b (see Piura (no. 2) and Camana (no. 22)); however, those effects were not noticeable in terms of the annual water balance disparity. Finally, the methodology made possible the separation of catchments with low and high water balance disparity related to low and high climatic and anthropogenic influence, respectively. Further research is needed to separate these two types of influences in the region.

\subsection{Hydroclimatic change disparity}

According to Fig. 4, most catchments move closer to the theoretical water and energy limits. Following the premise that 11 selected catchments have a "quasinatural" behavior with less anthropogenic and climatic influence, it is expected that these catchments move in all directions through Budyko space. The direction and magnitude of change is presented in Fig. 6a, b, respectively, where most of the years in all catchments are characterized by energy (i.e., $\mathrm{PET} / P<1$ ) and water limitations (i.e., $\mathrm{PET} / P>1$ ). Direction and magnitude values are provided in Table 4.

Figure $6 \mathrm{a}$ indicates two types of change adaptations represented mostly with green and red points in one group (i.e., toward more energy-limited environments to the left) and yellow and orange points in the other (i.e., toward more waterlimited environments to the right). Red and green points tend to be an energy-limited environment $(\mathrm{PET} / P<1)$ and those catchments are plotted in Fig. 7a. According to Table 3, these 

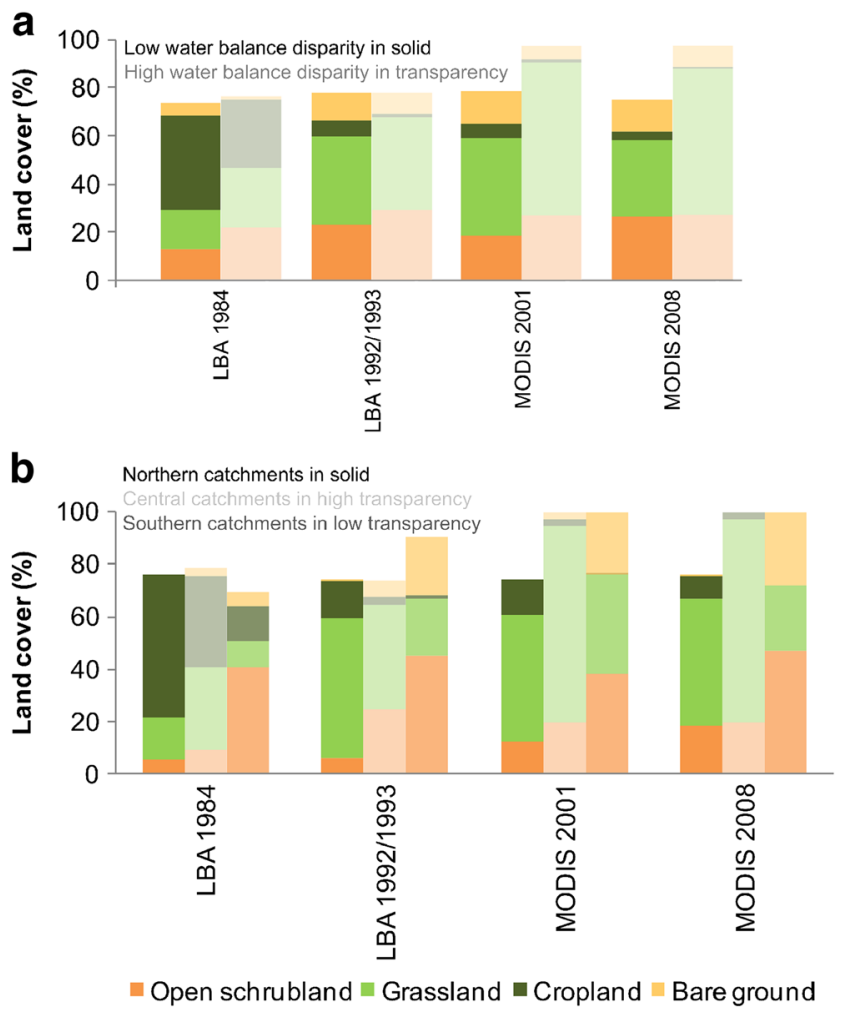

Fig. 5 Evolution of land cover (\%) with LBA and MODIS products over catchments grouped by a low and high water balance disparity. b Latitudinal gradient: northern catchments (no. 1 to no. 6), central catchments (no. 7 to no. 18), and southern catchments (no. 19 to no. 26)

catchments present a decrease in runoff, which can be explained by the increase of both $T$ and PET and the nonalteration in precipitation, concluding that those catchments have already the tendency to become less energy limited. The yellow and orange point groups present high values of $\mathrm{PET} / P$ representing strong variability of runoff and precipitation, corresponding to catchments with strong climatic influence such as the ENSO and semiarid conditions.

Figure $6 \mathrm{~b}$ shows two types of catchment sensitivity to climate variability (i.e., likely with high sensitivity to future climate) and land use changes, represented mostly with orange and yellow points in one group (i.e., toward more energylimited environments to the left) and red and purple points in the other (i.e., toward more water-limited environments to the right). A large change in magnitude means that climate- or human-induced changes were particularly large in this region and that any direction from Fig. 7a having a very small magnitude (see values in Table 4) can be considered as of little relevance (van der Velde et al. 2013). The orange and yellow point group has a low magnitude of change corresponding to catchments with low variability on precipitation and runoff. The red and purple point group coincides with catchments presenting significant variability in both precipitation and runoff. Figure $7 b$ shows the magnitude of change of the 11 selected catchments, and Table 4 shows (italicized) the six catchments identified as having major sensitivity.

They can be described in the light of Table 3 as follows: purple points represent the catchments of Piura (no. 2) and Yauca (no. 20), which are located mostly in a water-limited environment $(\mathrm{PET} / P>1)$ and where an increase in $P$ is likely to increase the assessment of AET through the Budyko equation (increase in PET due to increase in $T$ over the studied period has the opposite effect). As our results indicate that there is an increase in the AET in both cases with a significant increase in $P$ for Piura (no. 2) and a significant increase in $R$ for Yauca (no. 20), we conclude that an increase in precipitation is more likely to drive these ecosystem changes than the increase in temperature (i.e., increase in PET). Red points represent the catchments of Piura up (no. 1), Chicama (no. 5), San Juan (no. 17), and Acari (no. 19) which are located mostly in a water-limited environment. However, Piura up (no. 1) presents a decrease in AET, suggesting that both precipitation and temperature (i.e., increase in PET) drive these ecosystem changes. San Juan (no. 17) presents a decrease in $R$, and because of its location in both water- and energylimited environment, it suggests that both precipitation and temperature (i.e., increase in PET) drive these ecosystem changes. The remaining catchments, Chicama (no. 5) and
Fig. 6 Grouping of Budyko trajectories defined by their direction (a) and the magnitude (b) of change for the 11 selected catchments in the Budyko space over the 1970-2008 period
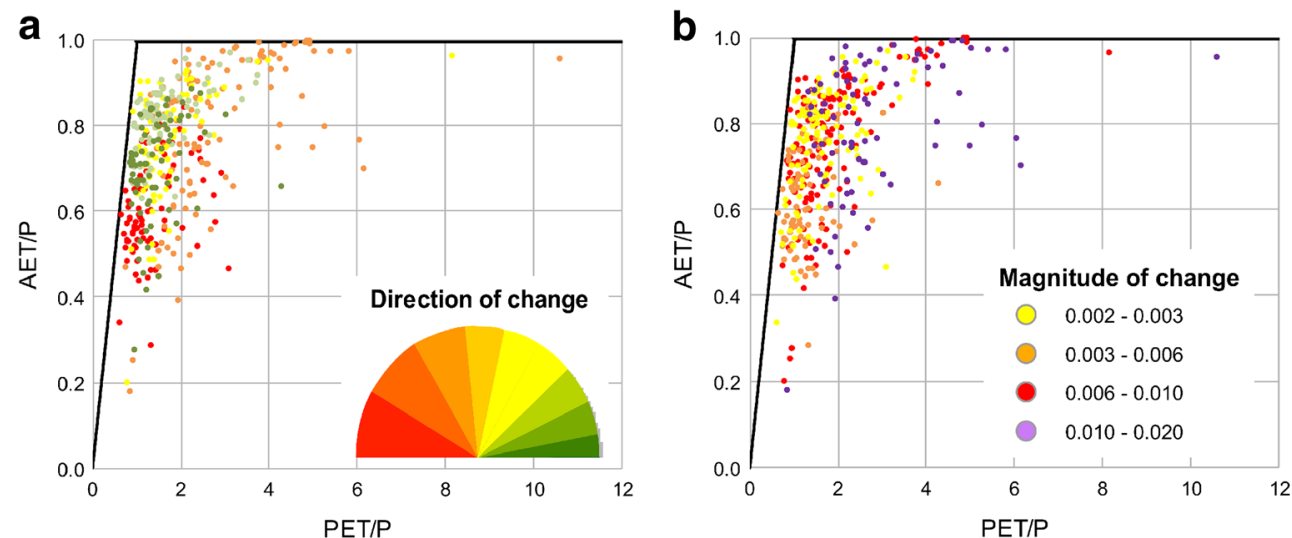
Fig. 7 Budyko trajectories defined by their direction (a) and magnitude (b) plotted across catchments. Red/orange, yellow, and green arrows in a show the three regions grouped by their hydroclimatic change adaptation. Purple and red points in $\mathbf{b}$ show the catchments with major sensitivity to climate variability and land use changes

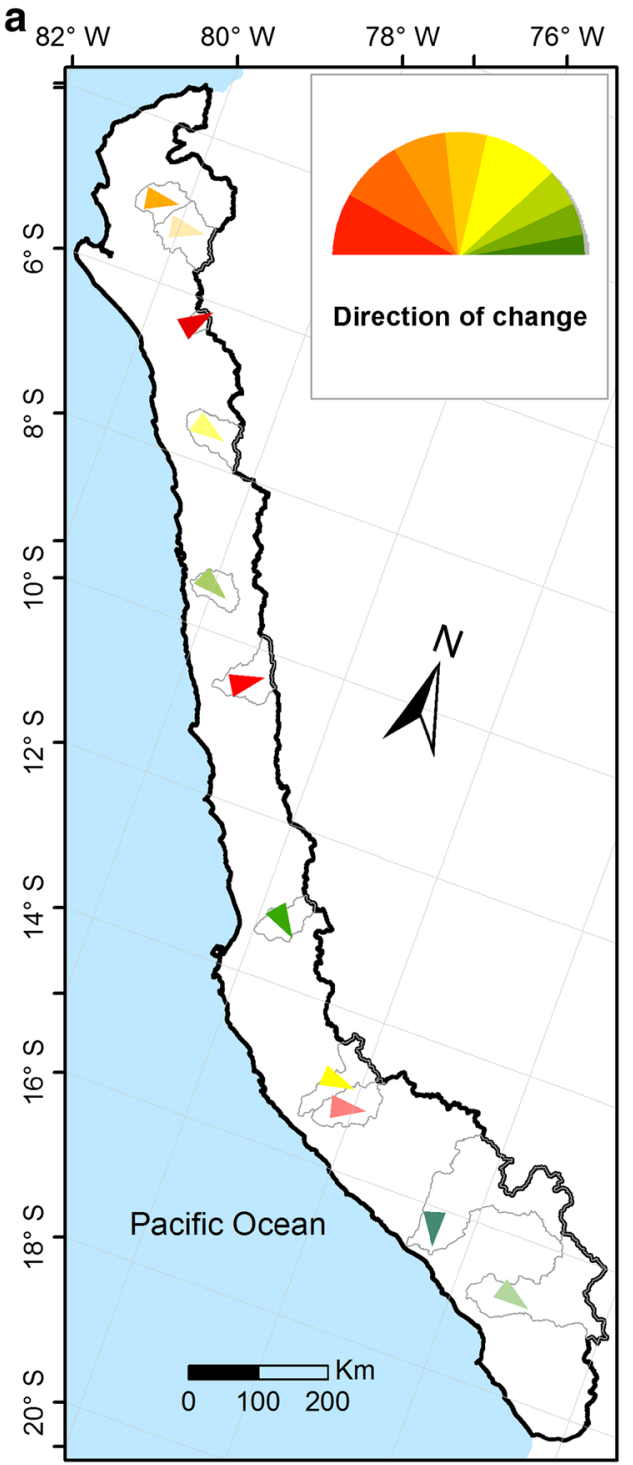

Table 4 Budyko trajectories defined by direction $(\alpha)$ and magnitude $(\beta)$ values across the selected catchments. Catchments with major sensitivity to climate variability and land use changes are italicized. Errors expressed in $(\%)$ were obtained via a 10 -year moving window

\begin{tabular}{llcl}
\hline No. & Catchment & $\alpha(\mathrm{deg})$ & $\beta(1 /$ year $)$ \\
\hline 1 & Piura up & $97(2 \%)$ & $0.009(30 \%)$ \\
2 & Piura & $99(1 \%)$ & $0.017(32 \%)$ \\
3 & La Leche & $138(1 \%)$ & $0.002(15 \%)$ \\
5 & Chicama & $75(6 \%)$ & $0.006(25 \%)$ \\
9 & Casma & $67(13 \%)$ & $0.002(46 \%)$ \\
11 & Pativilca & $124(3 \%)$ & $0.003(13 \%)$ \\
17 & San Juan & $49(9 \%)$ & $0.008(22 \%)$ \\
19 & Acari & $86(3 \%)$ & $0.007(25 \%)$ \\
20 & Yauca & $103(2 \%)$ & $0.010(27 \%)$ \\
22 & Camana & $16(32 \%)$ & $0.004(16 \%)$ \\
24 & Tambo & $73(3 \%)$ & $0.002(2 \%)$ \\
\hline
\end{tabular}

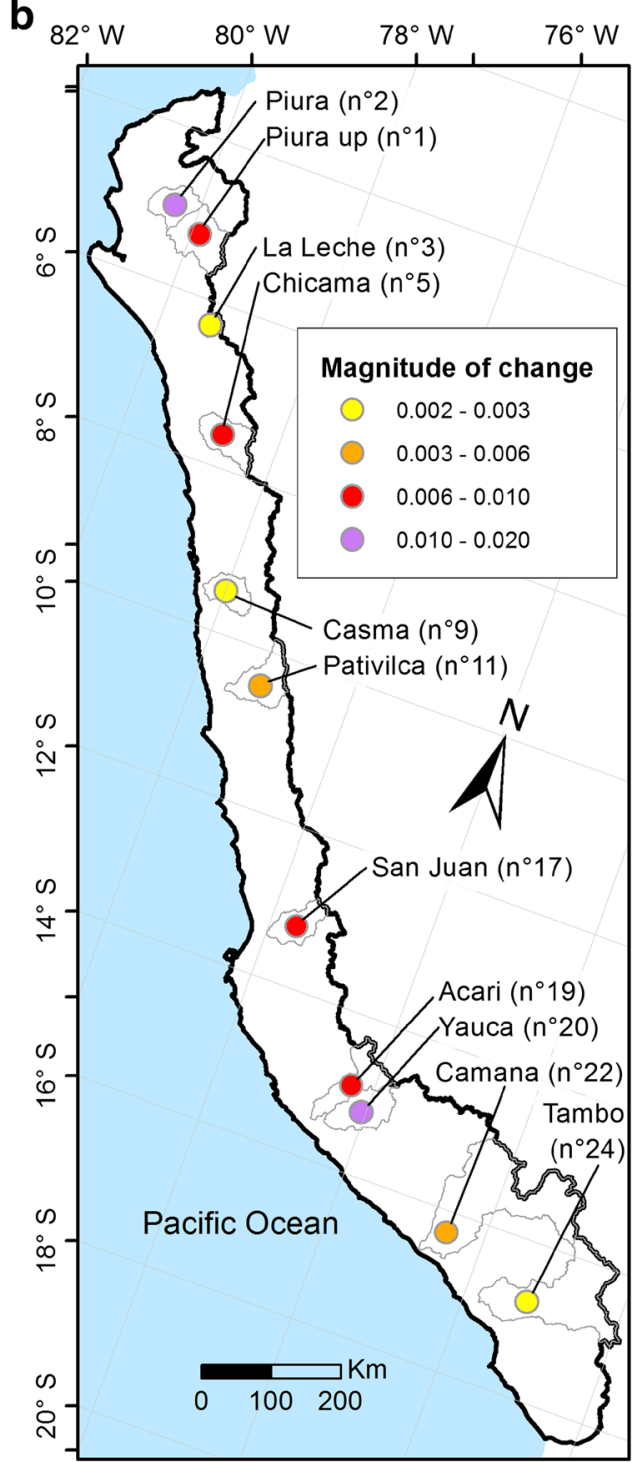

Acari (no. 19), suggest that an increase in precipitation is more likely to drive these ecosystem changes than the increase in temperature.

Piura upstream (no. 1) and Piura (no. 2) catchments exhibit a large increase in precipitation and runoff changes, and Chicama (no. 5) shows a large increase only in precipitation change, influenced by the ENSO climate conditions, and as shown in Fig. 2, those peaks are somehow inconsistent with the mean dry conditions.

It is worth pointing out that the hydrologic cycle of the 11 selected catchments is still influenced by human activities but only marginally (e.g., see changes in land cover in Fig. 5a). From an ecosystemic point of view and according to the Budyko theory (see van der Velde et al. 2013), in those "quasinatural" environments, any changes in vegetation are due to a co-evolution with the landscape to optimize water and energy use for given climatic 
conditions. It maintains a steady state. However, the anthropogenic influence prevents a natural adaptation of vegetation species, as expected under the co-evolution. Strong disturbance could modify this behavior (as found with the 15 remaining catchments) in a long term, where it would be valid to reconsider the statement of a steady state.

The direction and magnitude values in the Budyko relationship are presented in Table 4. Equations 4 and 5 were also validated over different periods through a 10 -year moving window along the 1970-2008 period, which yields a range of values expressed in error rates (\%).

\section{Conclusions}

This study analyzes the hydroclimatic variability over 26 catchments of the Peruvian Pacific drainage region for the 1970-2008 period. We applied the Budyko-Zhang methodology to analyze the water balance trends over the period and determine if climate variability or human activities may have influenced these trends.

The study area experienced greater precipitation and runoff changes over the northern latitudes in relation with the ENSO influence. PET has been also studied for the first time in the region as an approach to relate it with temperature (and its relationship with the altitudinal gradient) using the Oudin method. This method is suitable for regions with nondense climatic database as well as under arid and semiarid conditions. Annual values of PET decrease southward with a slight increase over most arid catchment located in the south due to a predominance of bare ground and open shrubland areas. According to significant upward trends in annual temperature found in all catchments and regional change points found in most catchments, our results showed a significant warming in the study area with a mean of $0.2{ }^{\circ} \mathrm{C}$ per decade as already identified in studies for South American Andes such as the one by Vuille et al. (2015). Precipitation data do not exhibit significant trends and change points in most catchments. The runoff time series presented a significant decrease over central catchments with a change point in the years 1987 and 1989, which is mainly related to the intensive water exploitation for agricultural activities and land cover change.

Following the hydroclimatic description of the region, we applied the Budyko-Zhang conceptual framework to identify plausible annual change disparity of water balance in catchments along the study area. This region is characterized mostly by semiarid conditions and presents strong climate variability mainly in the northern regions. We identified 11 out of 26 catchments with low disparity according to the BudykoZhang framework related to a low climatic and anthropogenic influence and suitable for an in-depth analysis with Budyko trajectories. The $w$ parameter related to plant-available water in the Budyko-Zhang framework reaches an average value of 0.7 , indicating the predominance of grasslands over the semiarid conditions. Besides having a climatic influence, large hydraulic systems and irrigation have been identified as one of the main factors of human activity causing significant changes in runoff in most catchments. Catchments with high water balance disparity presented a significant change in land cover mainly with a decrease in cropland and an increase in grassland over the studied period.

Changes in trajectories in the Budyko space over those 11 selected catchments revealed two groups of catchments. Six catchments - Piura upstream (no. 1), Piura (no. 2), Chicama (no. 5), San Juan (no. 17), Acari (no. 19), and Yauca (no. 20) - were shown to be sensitive to climate variability (i.e., likely with high sensitivity to future climate) and land use changes, where precipitation and temperature are the most likely drivers of these environments change. The five other catchments do not reveal any clear behavior in terms of sensitivity to climate variability.

Finally, depending on the observational period of the analysis, limitations are mostly related to limited hydroclimatic data availability and related to the steady-state hypothesis of the Budyko framework. However, despite these limitations, our results provide a first assessment of the catchments with less climate and anthropogenic influence on water balance and its sensibility to climate variability and land use change which has implication for regional water resources assessment and management.

Acknowledgements The authors would like to thank SENAMHI (Meteorological and Hydrological Service of Peru) for providing complete hydrometeorological raw dataset. We thank the anonymous reviewer for his constructive comments that helped improve the original manuscript. B. Dewitte acknowledges supports from FONDECYT (projects 1171861 and 1151185).

Funding information This work was supported by Peruvian Ministry of Education (MINEDU-PRONABEC scholarship).

\section{References}

ANA (2012) Recursos Hídricos en el Peru, 2nd edn. Ministerio de Agricultura. Autoridad Nacional del Agua, Lima, pp 45-189

Bourrel L, Rau P, Dewitte B, Labat D, Lavado W, Coutaud A, Vera A, Alvarado A, Ordoñez J (2015) Low-frequency modulation and trend of the relationship between ENSO and precipitation along the northern to centre Peruvian Pacific coast. Hydrol Process 29(6):12521266

Brouwer C, Heibloem M (1986) Irrigation water measurement: irrigation water needs, vol 3. United Nations Food and Agriculture Organization, Rome, p 102

Brown AE, Zhang L, McMahon TA, Western AW, Vertessy RA (2005) A review of paired catchment studies for determining changes in water yield resulting from alterations in vegetation. J Hydrol 310:28-61 
Budyko MI (1958) The heat balance of the Earth's surface. U.S. Department of Commerce, Washington, p 259

Budyko MI (1974) Climate and life. International geophysics series, vol 18. Academic, New York, p 508

Chen Z, Chen Y, Li B (2013) Quantifying the effects of climate variability and human activities on runoff for Kaidu River basin in arid region of northwest China. Theor Appl Climatol 111:537-545

Coron L, Andréassian V, Perrin C, Le Moine N (2015) Graphical tools based on Turc-Budyko plots to detect changes in catchment behaviour. Hydrol Sci J 60(7-8):1394-1407

DeFries R, Hansen M, Townshend JRG, Sohlberg R (1998) Global land cover classifications at $8 \mathrm{~km}$ spatial resolution: the use of training data derived from Landsat imagery in decision tree classifiers. Int $\mathrm{J}$ Remote Sens 19(16):3141-3168

Donohue RJ, Roderick ML, McVicar TR (2007) On the importance of including vegetation dynamics in Budyko's hydrological model. Hydrol Earth Syst Sci 11:983-995

Donohue RJ, Roderick ML, McVicar TR (2011) Assessing the differences in sensitivities of runoff to changes in climatic conditions across a large basin. J Hydrol 406:234-244

Greve P, Gudmundsson L, Orlowsky B, Seneviratne S (2015) Introducing a probabilistic Budyko framework. Geophys Res Lett 42(7):2261-2269

Hansen M, DeFries R, Townshend JRG, Sohlberg R (2000) Global land cover classification at $1 \mathrm{~km}$ resolution using a decision tree classifier. Int J Remote Sens 21:1331-1365

Hassan H, Dregne HE (1997) Natural habitats and ecosystems management in drylands: an overview. Environment department paper N51. World Bank, Washington, pp 1-53

Hublart P, Ruelland D, Dezetter A, Jourde H (2015) Reducing structural uncertainty in conceptual hydrological modelling in the semi-arid Andes. Hydrol Earth Syst Sci 19:2295-2314

Hublart P, Ruelland D, García de Cortázar-Atauri I, Gascoin S, Lhermitte S, Ibacache A (2016) Reliability of lumped hydrological modeling in a semi-arid mountainous catchment facing water-use changes. Hydrol Earth Syst Sci 20:3691-3717

Jaramillo F, Destouni G (2014) Developing water change spectra and distinguishing change drivers worldwide. Geophys Res Lett 41: $8377-8386$

Jones J, Creed I, Hatcher K, Warren R, Adams M, Benson M et al (2012) Ecosystem processes and human influences regulate streamflow response to climate change at long-term ecological research sites. Bioscience 62(4):390-404

Kendall MG (1975) Rank correlation measures. Charles Griffin, London, p 202

Lavado WS, Ronchail J, Labat D, Espinoza JC, Guyot JL (2012) Basinscale analysis of rainfall and runoff in Peru (1969-2004): Pacific, Titicaca and Amazonas drainages. Hydrol Sci J 57(4):625-642

Lavado WS, Labat D, Ronchail J, Espinoza JC, Guyot JL (2013) Trends in rainfall and temperature in the Peruvian Amazon-Andes basin over the last 40 years (1965-2007). Hydrol Process 27:2944-2957

Mann HB (1945) Non-parametric tests against trend. Econometrica 13: 245-259

Mortimore M (2009) Dryland opportunities. International Union for Conservation of Nature and Natural Resources. IUCN. IIED. UNDP, Gland-Switzerland, p 86
Oudin L, Hervieu F, Michel C, Perrin C, Andreassian V, Anctil F, Loumagne $C$ (2005) Which potential evapotranspiration input for a lumped rainfall-runoff model? Part 2-towards a simple and efficient potential evapotranspiration model for rainfall-runoff modeling. J Hydrol 303:290-306

Pettitt AN (1979) A non-parametric approach to the change-point problem. Appl Stat 28:126-135

Rau P, Bourrel L, Labat D, Melo P, Dewitte B, Frappart F, Lavado W, Felipe O (2016) Regionalization of rainfall over the Peruvian Pacific slope and coast. Int J Climatol. https://doi.org/10.1002/joc.4693

Renner M, Bernhofer C (2012) Applying simple water-energy balance frameworks to predict the climate sensitivity of streamflow over the continental United States. Hydrol Earth Syst Sci 16:2531-2546

Ruelland D, Dezetter A, Hublart P (2014) Sensitivity analysis of hydrological modelling to climate forcing in a semi-arid mountainous catchment. In: Hydrology in a changing world: environmental and human dimensions (Proc. 7th FRIEND-Water Int. Conf., Montpellier, France, 7-10 Oct. 2014). IAHS Publ 363:145-150

Searcy JK, Hardison CH (1960) Double-mass curves. US Geol Survey Water-Supply Paper 1541-B:31-66

Sivapalan M, Thompson SE, Harman CJ, Basu NB, Kumar P (2011) Water cycle dynamics in a changing environment: improving predictability through synthesis. Water Resour Res 47(10):W00J01

Valéry A, Andréassian V, Perrin C (2010) Regionalization of precipitation and air temperature over high-altitude catchments-learning from outliers. Hydrol Sci J 55(6):928-940

van der Velde Y, Vercauteren N, Jaramillo F, Dekker S, Destouni G, Lyon S (2013) Exploring hydroclimatic change disparity via the Budyko framework. Hydrol Process 28:4110-4118

Vuille M, Franquist E, Garreaud R, Lavado W, Caceres B (2015) Impact of the global warming hiatus on Andean temperature. J Geophys Res Atmos 120:3745-3757

Wagener T, Sivapalan M, Troch PA, McGlynn BL, Harman CJ, Gupta HV, Kumar P, Rao PSC, Basu NB, Wilson JS (2010) The future of hydrology: an evolving science for a changing world. Water Resour Res 46(5):W05301

Wang D, Hejazi M (2011) Quantifying the relative contribution of the climate and direct human impacts on mean annual streamflow in the contiguous United States. Water Resour Res 47(10):W00J12

Wang W, Shao Q, Yang T, Peng S, Xing W, Sun F, Luo Y (2013) Quantitative assessment of the impact of climate variability and human activities on runoff changes: a case study in four catchments of the Haihe river basin, China. Hydrol Process 27:1158-1174

Yang D, Shao W, Yeh P, Yang H, Kanae S, Taikan O (2009) Impact of vegetation coverage on regional water balance in the nonhumid regions of China. Water Resour Res 45:W00A14

Zhang L, Dawes WR, Walker GR (2001) The response of mean annual evapotranspiration to vegetation changes at catchment scale. Water Resour Res 37:701-708

Zhang S, Lu XX (2009) Hydrological responses to precipitation variation and diverse human activities in a mountainous tributary of the lower Xijiang, China. Catena 77:130-142

Zhao G, Mu X, Tian P, Wang F, Gao P (2013) Climate changes and their impacts on water resources in semiarid regions: a case study of the Wei River basin, China. Hydrol Process 27:3852-3863 